\title{
Antihyperglycemic and neuroprotective effects of Wattakaka volubilis (L.f.) Stapf root against streptozotocin induced diabetes
}

\author{
Hajira Banu Haroon, Anita Murali*
}

\author{
Department of Pharmacology, Faculty of Pharmacy, M. S. Ramaiah University of Applied Sciences, \\ Bengaluru, Karnataka, India
}

\begin{abstract}
Murva is an important drug in Ayurveda. Wattakaka volubilis is used as one of the botanical sources of Murva. The aim of this study is to evaluate the effect of the alcohol extract of $W$. volubilis root in streptoztocin (STZ) induced diabetes and diabetic neuropathy. Diabetes mellitus (DM) was induced by the administration of STZ (45 mg/kg, i.p). DM was induced within $72 \mathrm{~h}$. Diabetic animals were treated with glimepiride $(0.5$ $\mathrm{mg} / \mathrm{kg}$ ) and ethyl alcohol extract 100 and $200 \mathrm{mg} / \mathrm{kg}$ for $21 \mathrm{~d}$. After determining the changes in fasting serum glucose and lipid profile, animals were further treated for a period of $15 \mathrm{~d}$ to determine the protective effect of extract against diabetic neuropathy. All the alcohol extract treated animals, showed a significant decrease in serum glucose level $(\mathrm{P}<0.001)$, and overall decrease in the severity of diabetic neuropathy. Alcohol extract of $W$. volubilis root showed antihyperglycemic activity and beneficial protection against diabetic neuropathy and hence can be a promising agent for treatment and prevention of diabetic neuropathy.
\end{abstract}

Uniterms: Diabetes mellitus/study. Diabetic neuropathies. Wattakaka volubilis (L.f.) Stapf/ root/induced diabetes

\section{INTRODUCTION}

Diabetes is a serious metabolic disorder characterised by altered carbohydrate, lipid and protein metabolism which causes hyperglycemia resulting from insufficient insulin secretion, insulin action or both (Joseph, Jini, 2011).

Diabetic patients are predisposed to many problems associated with their disease and one of the most prevalent complications in diabetes is diabetic neuropathy which affects about $50 \%$ of diabetic patients. Diabetic neuropathy affects pain fibres, motor neurons, and the autonomic nervous system (Pirart, 1978), resulting in foot ulcers or injury leading to amputation in more than $80 \%$ of cases (Boulton et al., 2005). Several pathways originating from hyperglycemia induce oxidative stress leading to diabetic neuropathy viz. formation of advanced glycation end products (AGEs) (Sugimoto, Yasujima, Yagihashi, 2008), polyol pathway activation, aldol reductase activation (Srivastava, Ramana, Bhatnagar, 2005) and activation of protein kinase C (PKC) (Yamagishi et al., 2008).

\footnotetext{
*Correspondence: A. Murali. Department of Pharmacology. Faculty of Pharmacy, M. S. Ramaiah University of Applied Sciences. MSRIT Post, MSR Nagar, Bangalore-560054. Email id: anita.murali4@gmail.com
}

Due to its multifactorial nature, the treatment of this disease is difficult and treatment options are limited. This has led to increased exploration of alternative drugs from natural sources, having potent antidiabetic as well as neuroprotective activity.

Wattakaka volubilis (L.f) Stapf, a tall, woody climber belonging to the family Asclepiadaceae has been selected for the study. $W$. volubilis is also known as cotton milk plant and green wax flower (Gurudeva, 2001) and is used as an alternative source of Marsdenia tenacissima (Roxb.) Moon, which is the accepted botanical source of the drug Murva in Ayurveda (Yoganarasimhan, 2000). Murva is used for the treatment of colic pain and possesses purgative, anthelmintic, antimutagenic, anticancer, antibacterial properties and it is used as an ingredient in several Ayurveda formulations (Levekar et al., 2007).

The reported uses for $W$. volubilis are as follows. The plant juice is used as sternutatory and roots and tender stalks are used as emetic, purgative and expectorant (Yoganarasimhan, 2000). Leaves are used to treat rheumatic pain, cough, fever and severe cold (Muthu et al., 2006). The roots and leaves are used to treat skin diseases, diabetes, cough, jaundice, poison bites and for blood disorders (Rajadurai et al., 2009). Roots are used 
in the treatment of kidney stones; leaf paste is taken along with pepper to treat dyspepsia (Singh, Govil, Singh, 2007). It is also used to treat rheumatic pain, cough, fever, severe cold, boils and abscesses (Rajadurai et al., 2009; Silija, Varma, Mohanan, 2008). Paste of its bark is mixed with hot milk and used internally for treating urinary trouble. Powder of its leaves when taken leaf powder taken orally along with cow's milk is reported to have anti-diabetic activity (Pandi, Ayyanar, Ignacimuthu, 2007). Juice of leaf is used to cure sprain (Sanyasi, 2008). W. volubilis is also used in the treatment of scorpion and snake bites (Jain, Verma, 1981).

Several phytoconstituents have been reported on $W$. volubilis. Root revealed the presence of steroids, triterpenoids, phenolic compounds and flavonoids (Joshi, Anvekar, Bhobe, 2013). $N$-[4-bromo- $n$-butyl]2 -piperidinone and digitoxose have been isolated and characterized from the root (Joshi et al., 2013). Bark contained $\beta$-sistosterol, pregnane glycosides and kaempferol (Rastogi and Mehrotra, 1985). $\beta$-sitosterol; aglyconedrevogenin A; 9,12-octadecadienoic acid; quinic acid; 1,2- benzenedicarboxylic acid diisooctyl ester; 5,7-dihydroxy-6,8-dimethoxyflavone have been reported on the root (Joshi, Anvekar, Bhobe, 2013). HPTLC evaluation of methanol extract of leaf of $W$. volubilis revealed the presence of oleonolic acid and ursolic acid (Gopal, Mandal, Mandal, 2014).Three polyoxypregnane glycosides, volubiloside A, B and C were isolated from the flowers (Shau et al., 2002). An unusual triterpenoid ether, multiflor-7-en-12, 13-ether and a new multiflor7 -en-12 $\alpha$-ol was reported in the plant (Niranjan et al., 2002). Glycosides dregeosides H, Dp1, Da1, Gp1, Ga 1 and two biosides were isolated from the hydrolysate of glycosides from roots vide Rastogi and Mehrotra (1985). Seven new glycosides dregeosides Ap1, Ao1, Aa1, A11, $\mathrm{C} 11, \mathrm{Kp} 1$ and $\mathrm{Kal}$, Drevogenin D were isolated from the seeds. They were characterised as $3 \beta, 11 \beta, 12 \beta, 14 \beta$, $20 \xi$-pentahydroxypregn-5-enevide Rastogi and Mehrotra, (1980-1984).

$W$ volubilis root has been evaluated for antiurolithiatic (Singh, Govil, Singh, 2007) and antipyretic activities (Madhavan et al., 2010); leaf has been evaluated for anti-diabetic, anti-hyperlipidemic and antioxidant properties (Mohan, Maruthupandian, Sampathraj, 2010), wound healing property (Madhavan et al., 2012); antibacterial efficacy of root, stem and leaf have been reported (Shibu, Dhanam, 2013).Acute toxicity study of root also has been reported (Madhavan et al., 2010). The in vitro hypoglycaemic activity of Marsdenia tenacissima (Nayak, 2014) and antidiabetic activity of $W$. volubilis leaf have been scientifically validated, but no such study has been reported on root. Hence, the present study was undertaken to determine the anti-hyperglycemic activity of the alcohol extract of $W$. volubilis root and also to explore the possibility of its use in diabetic neuropathy.

\section{MATERIAL AND METHODS}

\section{Collection of plant material and preparation of ethanol extract}

The plant material was collected during March 2009 from Kalakkad forests, Tirunelveli district, Tamil Nadu in flowering condition. The plant was identified by Dr. S. N. Yoganarasimhan, Plant Taxonomist using Flora of the Presidency of Madras (2005) and Flora of Hassan District (1976). Herbarium specimen (031) was prepared as per Jain, Rao (1985) following International herbarium curatorial practices and deposited in the herbarium at the Department of Pharmacognosy, Faculty of Pharmacy, M. S. Ramaiah University of Applied Sciences, Bangalore.

Powdered shade dried root of $W$. volubilis was subjected to extraction with $95 \% \mathrm{v} / \mathrm{v}$ ethanol in a soxhlet apparatus by continuous hot percolation. The alcohol extract was filtered and concentrated to dryness. The percentage yield was calculated $(5.67 \% \mathrm{w} / \mathrm{w})$. The color and consistency of the extracts were noted (dark brown and sticky semisolid mass). The extract was suspended in $2 \% \mathrm{w} / \mathrm{v}$ acacia solution and used for further studies.

\section{Preliminary phytochemical analysis and HPTLC studies}

The alcohol extract was subjected to preliminary phytochemical analysis (Kokate, 1999) for detection of different constituents. Chromatographic studies were carried out following Harborne, (1998) and Stahl, (2005). HPTLC studies were carried out using Camag HPTLC system equipped with Linomat V applicator, TLC scanner 3, Reprostar 3 with 12bit CCD camera for photo documentation, controlled by Win CATS- 4 software. All the solvents used were of HPTLC grade obtained from MERCK. TLC aluminum sheet precoated with silica gel $60 \mathrm{~F} 254,(10 \times 10 \mathrm{~cm})$ was used as stationary phase. Chamber saturation was done overnight. Alcohol extract solution $(5 \mathrm{mg} / \mathrm{mL}, 4 \mu \mathrm{L})$, was applied in duplicate, as tracks 1-2, with a band length of $6 \mathrm{~mm}$ each on a precoated silica-gel 60 F254 TLC plate, with Linomat V applicator using a Hamilton syringe. No prewashing of the plate was done. The mobile phase used was chloroform: methanol (8:2). Chamber was saturated overnight. TLC plates were kept for development, to a migration distance of $90 \mathrm{~mm}$ 
for alcohol. No post derivatization was done for alcohol extract. The developed plates were dried and scanned successively at wavelengths of $254 \mathrm{~nm}, 366 \mathrm{~nm}$ and 425 $\mathrm{nm}$, band width, slit dimension, scanning speed and the source of radiation was deuterium, tungsten and mercury. The $\mathrm{Rf}$ and peak area of the spots were interpreted by using software (Wagner, Bladt, 1996).

\section{Animals}

Inbred albino Wistar rats, 8-12 weeks old, weighing 200-250 g of either sex were used in the study. The rats were kept in properly numbered large polypropylene cages with stainless steel top grill having facilities for pelleted food. The animals were maintained in $12 \mathrm{~h}$ light and dark cycle at $28{ }^{\circ} \mathrm{C} \pm 2{ }^{\circ} \mathrm{C}$ in a well-ventilated animal house under natural conditions and were acclimatized to laboratory conditions for 10 days prior to the commencement of the experiment. Paddy husk was used as bedding material. The animals were fed with standard pelleted diet. Prior approval was obtained from the Institutional Animal Ethics Committee of the institution (IEAC certificate no. MSRCP/M-41/2014).

\section{Acute toxicity study}

Limit test at $2000 \mathrm{mg} / \mathrm{kg}$ was performed as per OECD guidelines 423. Female albino Wistar rats were used in the study. A limit test at $2000 \mathrm{mg} / \mathrm{kg}$ was performed. The alcohol extract was administered orally to 6 animals. Animals are observed individually after dosing at least once during the first 30 minutes, periodically during the first 24 hours, with special attention given during the first 4 hours, and daily thereafter, for a total of 14 days.

\section{Induction of diabetes (Vogel et al., 2002)}

Standardization of STZ dose was done at doses 35, $45,50,55,60$ and $65 \mathrm{mg} / \mathrm{kg}$ with 3 animals at each dose level. Based on the observations, $45 \mathrm{mg} / \mathrm{kg}$ was selected as the dose for further studies.

Animals were challenged with single injection of streptozotocin (STZ) at the dose of $45 \mathrm{mg} / \mathrm{kg}$, i.p. After the injection, animals were allowed to drink 5\% glucose solution overnight (Koneri et al., 2014). Development of hyperglycemia was confirmed $72 \mathrm{~h}$ after STZ injection.

\section{Experimental design}

Non diabetic rats were assigned as the normal control group (Group I) and the rats with fasting serum glucose levels above $180 \mathrm{mg} / \mathrm{dl}$ at $72 \mathrm{~h}$ after STZ injection were considered diabetic and were divided into four groups of six animals each as follows:

Group II (Positive control) - Vehicle treated (Acacia 2\% w/v p.o) treated diabetic rats;

Group III (Standard) - Glimepiride treated $(0.5 \mathrm{mg} / \mathrm{kg}$, b.w, p.o) diabetic rats;

Group IV - Alcohol extract treated (100 mg/kg, b.w, p.o) diabetic rats;

Group V - Alcohol extract treated (200 mg/kg, b.w, p.o) diabetic rats.

The treatment was started $72 \mathrm{~h}$ (considered as day 1) post induction of diabetes. The animals were treated once daily for a period of 21 days. On the $22^{\text {nd }}$ day, animals were made to fast overnight, anaesthetized with anaesthetic ether and blood was withdrawn from the retro orbital plexus. Serum was separated from the blood by centrifuging at $3000 \mathrm{rpm}$ for $10 \mathrm{~min}$ (Micro Centrifuge, REMI Motors Ltd Mumbai)and the following parameters fasting blood glucose (Trinder, 1969), triglyceride (TG) (Abell, 1958) total cholesterol (TC) (Assmann., 1990; Bablock, 1988), albumin (Dumas, Watson, Biggs, 1997), High density lipoprotein (HDL) (Assmann, Schriewer, Schmitz, 1983) were estimated.

\section{Diabetic neuropathy}

Treatment was continued from the $22^{\text {nd }}$ day onwards for further $15 \mathrm{~d}$ to evaluate the effects of the extract on diabetic neuropathy. Response of diabetic animals to pain stimuli was measured by Eddy's hot plate method and acetic acid induced writhing test (Koneri et al., 2014). The response of animals to pain stimuli was assessed to study the effects of $W$. volubilis root extract on diabetes induced neuropathy.

\section{Analgesic activity by Eddy's hot-plate method}

Each rat was placed on the hot plate maintained at $55-56^{\circ} \mathrm{C}$ and the time taken for the response to occur (either licking of paw or jumping) was recorded. A cut off time of $15 \mathrm{~s}$ was kept to avoid damage to the paw of the animal.

\section{Acetic acid writhing method}

Animals were treated with $1 \% \mathrm{v} / \mathrm{v}$ acetic acid and placed individually under observations. The number of abdominal contractions, trunk twist response and extension of hind limbs response during a period of 10 min were measured.

Subsequently, the animals were sacrificed for isolation of liver to estimate the glycogen content (Carroll, Longley, Roe, 1955; Van Der Vies, 1954). 


\section{Statistical Analysis}

The data were expressed as Mean \pm S.E.M and were tested with one way ANOVA followed by Tukey-Kramer multiple comparison test

\section{RESULTS}

\section{Phytochemical studies}

Preliminary phytochemical analysis of the alcohol extract of $W$. volubilis root revealed the presence of saponins and glycosides.

HPTLC fingerprint of the alcohol extract of $W$. volubilis root was obtained at wavelengths 254,366 and $425 \mathrm{~nm}$. At $254 \mathrm{~nm}, 3$ peaks were observed at $\mathrm{R}_{\mathrm{f}} 0.28,0.34$, $0.66 ; 13$ peaks were observed at $R_{f} 0.12,0.23,0.31,0.41$, $0.45,0.52,0.56,0.60,0.67,0.69,0.80,0.86$ and 0.93 at 366 $\mathrm{nm}$ and 4 peaks at $\mathrm{R}_{\mathrm{f}} 0.27,0.55,0.72,0.92$ were observed at $425 \mathrm{~nm}$ (Figure 1).

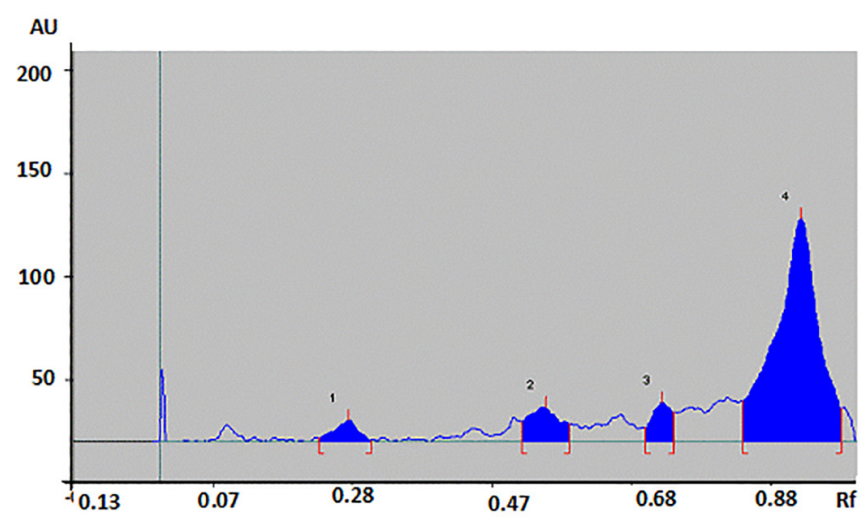

FIGURE 1 - HPTLC fingerprint of alcohol extract of $W$. volubilis root at $425 \mathrm{~nm}$.

\section{Acute toxicity study}

Oral administration of ethanol extract of $W$. volubilis at $2000 \mathrm{mg} / \mathrm{kg}$ did not produce any symptoms of toxicity or death in female Wistar rats. The doses for the pharmacological studies were chosen based on these results.

\section{Effect on body weight}

There was an increase in the mean body weight of normal control from $224.5 \pm 4.682 \mathrm{~g}$ on day 1 to $252.33 \pm 2.12 \mathrm{~g}$ on day 21 . There was a significant decrease in the body weight $(\mathrm{P}<0.001)$ of untreated diabetic rats from $211.16 \pm 2.89 \mathrm{~g}$ on day 1 to $51.83 \pm 2.70 \mathrm{~g}$ on day 21 . Animals treated with the extract significantly $(\mathrm{P}<0.001)$ gained weight and the observations were comparable with glimepiride $(0.5 \mathrm{mg} / \mathrm{kg})$ (Table I).

\section{Effect on serum parameters}

\section{Serum glucose}

Administration of streptozotocin $45 \mathrm{mg} / \mathrm{kg}$, b.w, i.p, produced significant $(\mathrm{P}<0.001)$ increase in blood glucose levels compared to the normal control animals. Diabetic rats treated with 100 and $200 \mathrm{mg} / \mathrm{kg}$ b.w of the alcohol extract showed fasting serum glucose levels of 197.63 \pm 1.25 and $201.34 \pm 2.93 \mathrm{mg} / \mathrm{dl}$ on day 0 which was significantly reduced to $169.83 \pm 2.11$ and $131.37 \pm 2.07$ $\mathrm{mg} / \mathrm{dl}$ on day 21 respectively. Results were statistically significant $(\mathrm{P}<0.001)$ (Table I).

\section{Lipid profile}

The STZ induced diabetic rats (positive control) showed significant $(\mathrm{P}<0.001)$ elevation of serum cholesterol, serum triglyceride levels and reduction in HDL levels compared to the normal control. There was a significant $(\mathrm{P}<0.001)$ reduction in the serum cholesterol, serum triglyceride levels and significant elevation in serum HDL levels in all the extract treated (100 and $200 \mathrm{mg} / \mathrm{kg}$ ) and glimepiride treated groups (Table II).

\section{Serum albumin}

Serum albumin concentration in the positive control was $2.60 \pm 0.11 \mathrm{~g} / \mathrm{dLwhich}$ was significantly lower $(\mathrm{P}<0.001)$ than that of normal control $(6.10 \pm 0.03$ $\mathrm{g} / \mathrm{dL})$. An elevation in serum albumin levels $(\mathrm{P}<0.001)$ were observed in extract treated (100 and $200 \mathrm{mg} / \mathrm{kg}$ ) and glimepiride treated groups of diabetic rats (Table II).

\section{Liver glycogen}

The liver glycogen content in normal group and positive control group of rats was found to be $2681.59 \pm$ $67.56 \mathrm{mg}$ and $788.60 \pm 20.5 \mathrm{mg}$ respectively. This shows that there was a significant decrease $(\mathrm{P}<0.001)$ in liver glycogen content in the diabetic control when compared with the normal control animals. Treatment with 100, $200 \mathrm{mg} / \mathrm{kg}$ of alcohol extract and glimepiride showed significant improvement $(\mathrm{P}<0.001)$ in liver glycogen content. Results are tabulated in (Table II).

\section{Effects on diabetic neuropathy}

The response to pain stimuli was assessed by hot plate method and acetic acid writhing methods.

Hot plate response time in STZ diabetic rats $(12.33 \pm 0.71 \mathrm{~s})$ was found to be significantly higher 
TABLE I - Effect of alcohol extract of $W$. volubilis root on body weight and serum glucose in Wistar rats

\begin{tabular}{lcccc}
\hline \multirow{2}{*}{ Groups } & \multicolumn{2}{c}{ Body weight } & \multicolumn{2}{c}{ Serum glucose (mg/dL) } \\
\cline { 2 - 5 } & Before treatment & after treatment & before treatment & after treatment \\
\hline Normal control (2\% w/v acacia) & $224.5 \pm 4.68$ & $252.33 \pm 2.12$ & $88.70 \pm 1.17$ & $97.40 \pm 1.42$ \\
Diabetic control & $211.16 \pm 2.89$ & $51.83 \pm 2.70^{\mathrm{a}}$ & $191.20 \pm 3.30$ & $226.90 \pm 2.66^{\mathrm{a}}$ \\
Standard (Glimepiride) & $211.33 \pm 2.87$ & $189.5 \pm 3.00^{* * *}$ & $197.60 \pm 1.33$ & $125.70 \pm 2.60^{* * *}$ \\
Alcohol extract (100 $\mathrm{mg} / \mathrm{kg})$ & $217.33 \pm 2.26$ & $167.33 \pm 2.44 * * *$ & $197.63 \pm 1.25$ & $169.83 \pm 2.11 * * *$ \\
Alcohol extract $(200 \mathrm{mg} / \mathrm{kg})$ & $214.16 \pm 2.00$ & $176.66 \pm 3.50^{* * *}$ & $201.34 \pm 2.93$ & $131.37 \pm 2.07 * * *$ \\
\hline
\end{tabular}

Values are expressed as Mean \pm SEM; $n=6$. One-way ANOVA: P value found to be 0.0001 ; Tukey-Kramer multiple comparisons test: ${ }^{a} \mathrm{P}<0.001$ in comparison with normal control; ${ }^{* * *} \mathrm{P}<0.001$ in comparison with the positive control

TABLE II - Effect of alcohol extract of $W$. volubilis root on serum parameters in Wistar rats

\begin{tabular}{|c|c|c|c|c|c|}
\hline Parameters & Normal control & Diabetic control & $\begin{array}{c}\text { Standard } \\
\text { (Glimepiride) }\end{array}$ & $\begin{array}{c}\text { Alcohol extract } \\
(100 \mathrm{mg} / \mathrm{kg})\end{array}$ & $\begin{array}{c}\text { Alcohol extract } \\
(200 \mathrm{mg} / \mathrm{kg})\end{array}$ \\
\hline$\overline{\text { Serum TG (mg/dL) }}$ & $139.74 \pm 2.36$ & $196.35 \pm 6.64^{\mathrm{a}}$ & $158.00 \pm 1.51^{* * *}$ & $140.30 \pm 3.14^{* * *}$ & $117.30 \pm 2.75^{* * *}$ \\
\hline Serum albumin $(g / d L)$ & $6.10 \pm 0.03$ & $2.60 \pm 0.11^{\mathrm{a}}$ & $5.17 \pm 0.25^{* * *}$ & $6.01 \pm 0.13^{* * *}$ & $5.65 \pm 0.12^{* * * *}$ \\
\hline Serum HDL (mg/dl) & $81.78 \pm 1.87$ & $35.75 \pm 2.07^{\mathrm{a}}$ & $57.09 \pm 1.61^{* * * *}$ & $101.90 \pm 2.14^{* * *}$ & $92.53 \pm 2.93^{* * *}$ \\
\hline
\end{tabular}

Values are expressed as Mean \pm SEM; $n=6$. One-way ANOVA: P value found to be 0.0001 ; Tukey-Kramer multiple comparisons test: ${ }^{a} \mathrm{P}<0.001$ in comparison with normal control; ${ }^{* * *} \mathrm{P}<0.001$ in comparison with the positive control

$(\mathrm{P}<0.001)$ than the normal rats $(1.66 \pm 0.33 \mathrm{~s})$. Hot plate response time in $\mathrm{STZ}$ diabetic rats administered with alcohol extract $100,200 \mathrm{mg} / \mathrm{kg}$ and glimepiride $(0.5 \mathrm{mg} /$ $\mathrm{kg}$ ) was found to be $4.83 \pm 0.30 \mathrm{~s}, 3.83 \pm 0.30 \mathrm{~s}$ and $5.0 \pm 0.60$ $\mathrm{s}$, respectively, which was significantly lower $(\mathrm{P}<0.001)$ than that of diabetic control.

Diabetic control rat showed $8.5 \pm 1.0$ writhing in ten minutes which is significantly lower $(\mathrm{P}<0.001)$ in comparison with the normal group ( $32.66 \pm 0.88$ writhing in ten minutes). Number of writhing showed by diabetic rats administered with $100,200 \mathrm{mg} / \mathrm{kg}$ and glimepiride was found to be $14.83 \pm 1.42,19.66 \pm 1.43$ and $15.66 \pm 0.66$, respectively, which was significantly higher $(\mathrm{P}<0.001)$ than the results observed with the diabetic control. Results are presented in Table III.

\section{Histopathology examination}

Liver-histologic examination of liver of normal rats showed normal hepatic architecture with a central vein while the diabetic liver showed periportal fatty infiltration with focal fat necrosis, lymphocyte infiltration, ballooning degeneration and dilated sinusoids. The extract as well as glimepiride treated diabetic rats showed

TABLE III - Effect of alcohol extract of $W$. volubilis root on diabetic neuropathy in Wistar rats

\begin{tabular}{lcc}
\hline Groups & Hot plate response time (s) & No. of writhing in ten min \\
\hline Normal control (2\% w/v acacia) & $1.66 \pm 0.33$ & $32.66 \pm 0.88$ \\
Diabetic control & $12.33 \pm 0.71^{\mathrm{a}}$ & $8.5 \pm 1.00^{\mathrm{a}}$ \\
Standard (Glimepiride) & $5.0 \pm 0.60^{* * *}$ & $15.66 \pm 0.66^{* *}$ \\
Test $1(100 \mathrm{mg} / \mathrm{kg})$ & $4.83 \pm 0.30^{* * * *}$ & $14.83 \pm 1.42^{\text {****}}$ \\
Test $2(200 \mathrm{mg} / \mathrm{kg})$ & $3.83 \pm 0.30^{* * * *}$ & $19.66 \pm 1.43^{\text {****}}$ \\
\hline
\end{tabular}

Values are expressed as Mean \pm SEM; $n=6$. One-way ANOVA: $\mathrm{P}$ value found to be $<0.0001$; Tukey-Kramer multiple comparisons test: ${ }^{\mathrm{P}}<0.001$ in comparison with normal control; ${ }^{* * *} \mathrm{P}<0.001$ in comparison with positive control; ${ }^{* *} \mathrm{P}<0.01$ in comparison with positive control 
normal hepatic architecture with narrower sinusoids (Figure 2A-2E).

Pancreas-Histologic examination of pancreas in normal rats revealed normal architecture showing pancreatic acini and connective tissue. The diabetic group showed highly dilated blood vessels and marked degeneration in pancreas. The extract treated groups as well as glimepiride treated group showed normal lobular architecture with connective tissue (Figure 3A-3E).
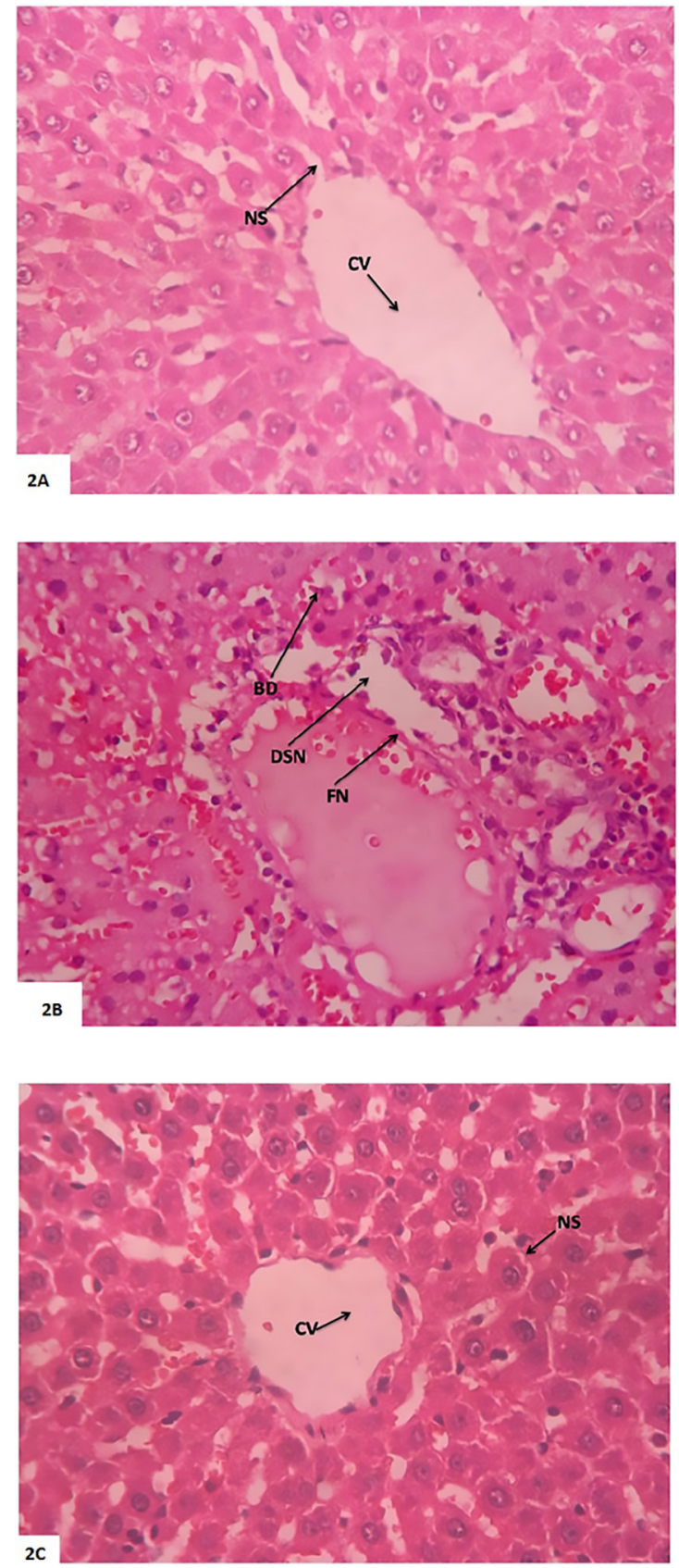

\section{DISCUSSION}

Streptozotocin, a broad spectrum antibiotic which has been widely used for inducing the diabetes mellitus in a variety of animals by causing degeneration and necrosis of pancreatic $\beta$-cells (Junod et al., 1969). STZ is a 2-deoxy-glucose derivative of the carcinogen $\mathrm{N}$-methyl- $\mathrm{N}$-nitrosourea (MNU) and belongs to a group of alkylating antineoplastic drugs known as alkylating
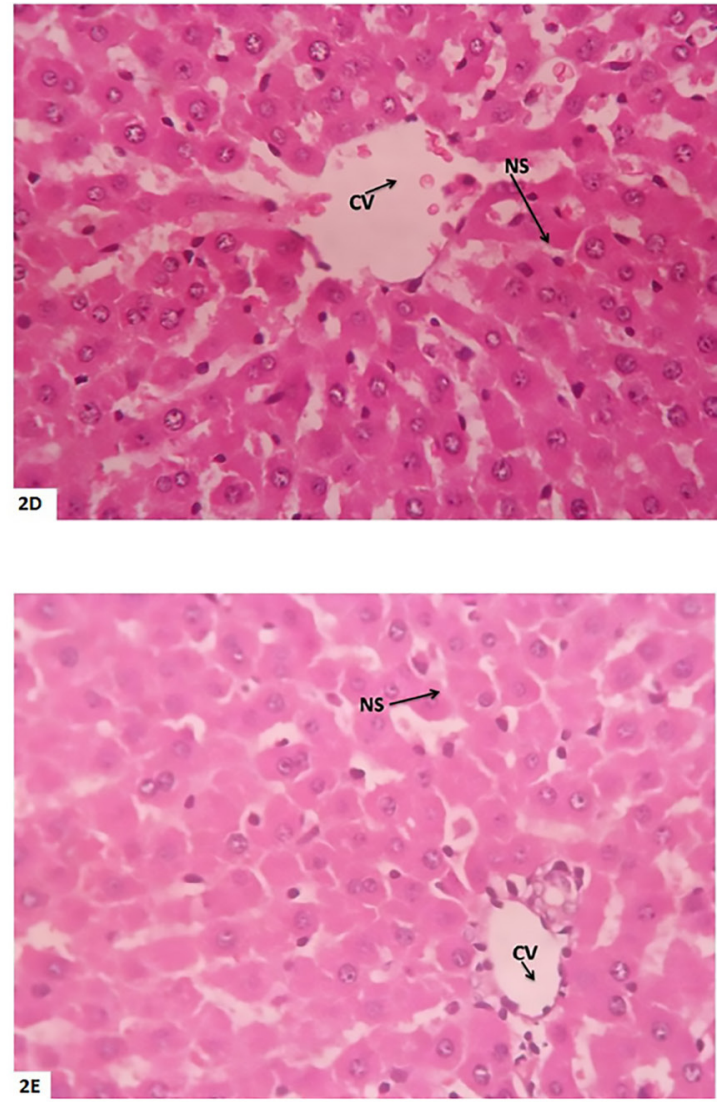

FIGURE 2 - A - Liver normal control; B-Diabetic control; C-Standard (glimepiride); D-Alcohol extract (100 mg/kg); E-Alcohol extract $(200 \mathrm{mg} / \mathrm{kg})$. CV-Central vein; NS- Narrow sinusoids; DSN-Dilated sinusoids; FN-Fatty necrosis; BD-Ballooning degradation. 

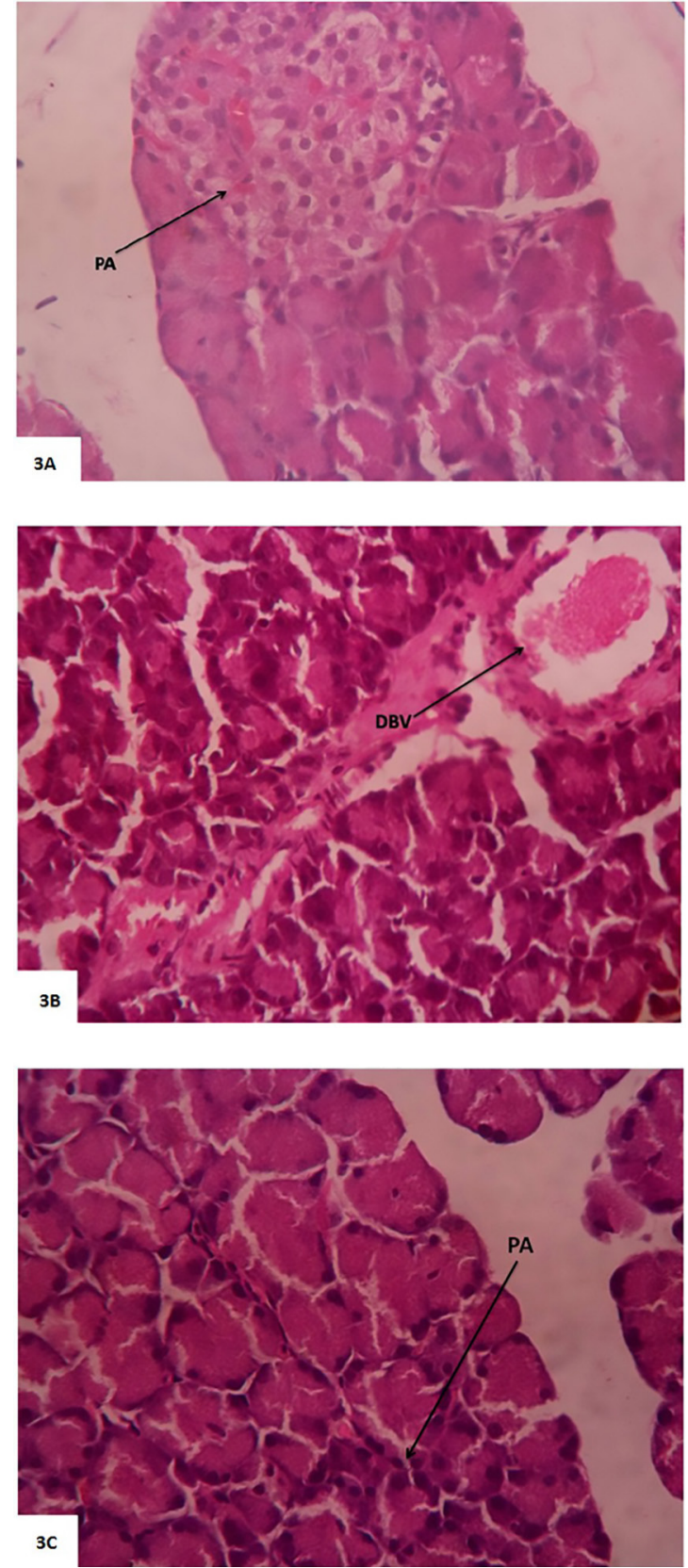
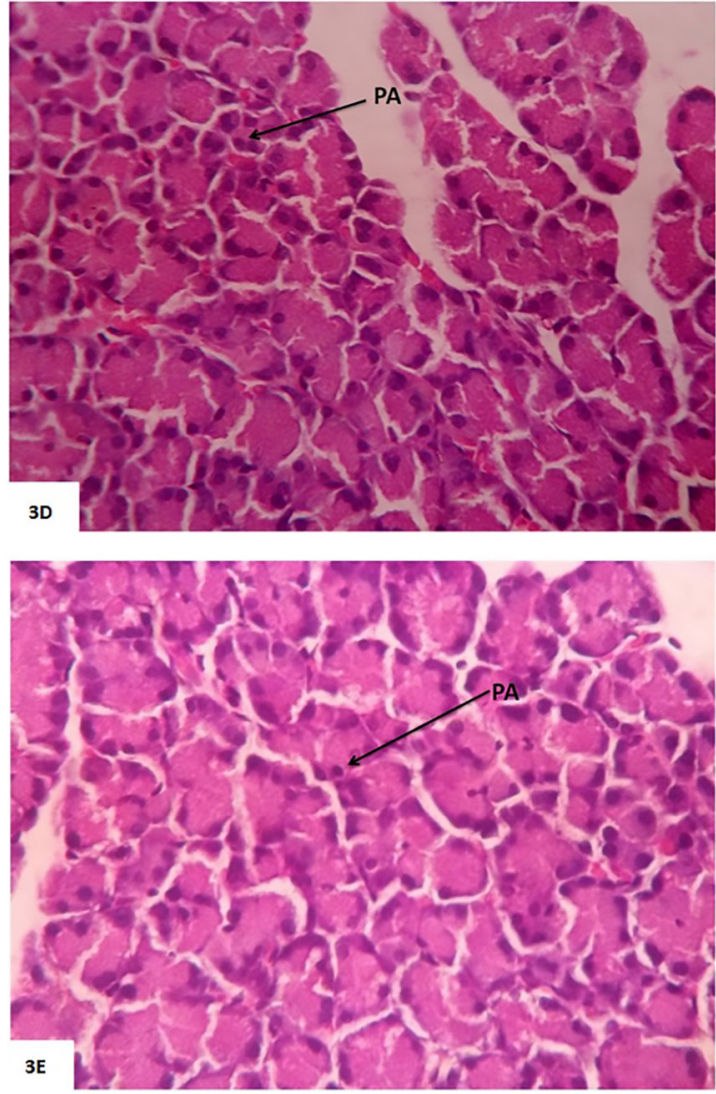

FIGURE 3 - A-Pancreas normal control; B-Diabetic control; C-Standard (glimepiride); D-Alcohol extract (100 mg/kg); E- Alcohol extract (200 mg/kg). PA-Pancreatic acini; DBV- Dilated blood vessels.

nitrosoureas (Bolzain, Bianchi, 2002). It is taken up by the pancreatic $\beta$-cells via glucose transporter GLUT2. STZ imposes toxicity on pancreatic $\beta$-islet cells (Rodrigues et al., 1997). By DNA modification through free radicals mechanism and DNA methylation STZ causes direct alkylation of DNA by reactive methyl carbonium ions $\left({ }^{\circ} \mathrm{CH}_{3}, \mathrm{CH}_{3}^{+}\right)$formed during the decomposition. Selection of an appropriate dose of STZ is a very important issue. Owing to strain differences (Rodrigues et al., 1997), the diabetogenic doses of STZ range from 45 to $70 \mathrm{mg} / \mathrm{kg}$
(Rakieten, Rakieten, Nadkarni, 1963).

In the present study, different doses of STZ were initially used for the standardisation of the dose for the development of DM. Doses 35, 45, 50, 55, 60 and $65 \mathrm{mg} /$ $\mathrm{kg}$ of STZ were administered. Injection of STZ produced abnormal abdominal contractions similar to writhing response for a brief period of time. During this evaluation, mortality was observed within $72 \mathrm{~h}$ in all animals receiving $50,55,60,65 \mathrm{mg} / \mathrm{kg}$ i.p. of STZ. Animals receiving the dose of $35 \mathrm{mg} / \mathrm{kg}$ i.p of STZ did not show any significant 
increase in the blood glucose level. All animals which received $45 \mathrm{mg} / \mathrm{kg}$ i.p of STZ showed hyperglycemia $72 \mathrm{~h}$ after induction. Further, administration of $5 \%$ glucose solution during the first $24 \mathrm{~h}$ following STZ injection prevented early mortalities (Suresh, Srinivasan, 1997).

STZ at a dose of $45 \mathrm{mg} / \mathrm{kg}$ was used for the induction of DM as it showed significant hyperglycemia without any mortality. All the animals manifested with major clinical sign of DM such as polyphagia, polydypsia, polyuria and body weight reduction. Diarrhoea was observed in the initial few $d$. This was followed by development of constipation characterized by bulged abdomen.

Doses of 100 and $200 \mathrm{mg} / \mathrm{kg}$ of the alcohol extract of $W$. volubilis were selected for the antidiabetic activity studies based on the results of acute toxicity studies. The alcohol extract of $W$. volubilis root at a dose of 100 and $200 \mathrm{mg} / \mathrm{kg}$ showed significant antihyperglycemic activity against STZ induced diabetes mellitus in rats, and the effects were comparable with that of the standard drug glimepiride.

Loss in body weight was observed in STZ-induced DM in rats and was controlled by treatment with alcohol extract of $W$. volubilis root. Administration of the extract to diabetic rats resulted in an increase in body weight. The findings of this study suggest that $W$. volubilis has a positive effect on maintaining body weight in diabetic animals.

Treatment of diabetic rats with different doses of alcohol extract reduced the elevated serum glucose at both the test dose levels, but the higher dose $(200 \mathrm{mg} / \mathrm{kg})$ was able to reduce the fasting serum glucose comparable with the reduction caused by treatment with glimepiride during the period of study.

Diabetes mellitus is usually associated with prominent levels of serum lipids and such an increase causes the risk factor for coronary heart diseases (Davidson, 1981). A variety of alterations in metabolic and regulatory mechanisms, due to insulin deficiency or due to insulin resistance are responsible for the observed accumulation of lipids (Rajalingam, Srinivasan, Govindarajulu, 1993). High levels of TC and TG are the predictors of atherosclerosis (Temme et al., 2002). In the present study, the test extract significantly reduced the TC and TG levels in treated diabetic rats compared to untreated diabetic rats. In fact, the TC and TG levels were lowered more significantly in the test dose group $(200 \mathrm{mg} / \mathrm{kg}$ ) than the standard (glimepiride) treated group. Several studies showed that increase in HDL cholesterol is associated with a decrease in coronary risk (Rajalingam, Srinivasan, Govindarajulu, 1993). In the present study, the extract significantly increased the levels of HDL cholesterol. This is an important advantage in treatment of hypercholesterolemia particularly in patients in whom low HDL cholesterol levels remain the most prevalent lipoprotein abnormality in DM (Gupta et al., 1994).

Diabetes is associated with a decrease in liver weight due to enhanced catabolic processes such as glycogenolysis, lipolysis and proteolysis (Yadav et al., 2005 ) and therefore the quantification of glycogen, the primary intracellular storage form of glucose in liver can be considered as an important indicator of diabetes mellitus. Glycogen level in various tissues especially in liver and skeletal muscle indicates direct reflection of insulin activity since it causes glycogen deposition by stimulating glycogen synthase and inhibiting glycogen phosphorylase. Glycogen levels in tissues (muscle and liver) decrease as the influx of glucose in the liver is inhibited in the absence of insulin and recovers on insulin treatment (Ghahary et al., 1991).Treatment with the extract significantly increased the hepatic glycogen levels in the extract treated rats.

Diabetic neuropathy is one of the common complications of diabetes mellitus. It affects all the peripheral nerves including pain fibres, motor neurons, and the autonomic nervous system (Pirart, 1978). There is a loss of pain perception in diabetes probably due to nerve damage and induction of peripheral neuropathy (Raz et al., 1988; Simon, Dewey, 1981). Thermal hypoalgesia has been reported in diabetic rats using the hot-plate test. In this study, streptozotocin-induced diabetic control rats showed significant hypoalgesia in the hot-plate (Tulaporn, Sithiporn, 2009; Zochodne et al., 2001).Acetic acid induced writhing was also evaluated as a parameter to demonstrate the pain sensitivity in diabetic animals. It was observed that animals treated with the extracts showed increased pain perception than the diabetic control or the standard group. This indicates the protective effect of the extract against diabetic neuropathy.

The findings of this study proved the antihyperglycemic activity and neuroprotective effects of $W$. volubilis root. However, the glycemic levels could not be normalized by the 21 day treatment period. However, considering the short duration of the present study, a longer duration of study is required to attain normal glycemic levels in blood.

Preliminary phytochemical analysis revealed the presence of glycosides and saponins. Several authors have reported the antidiabetic principles of saponins (Li et al., 2002; Jang et al., 2000). Hence, the antihyperglycemic activity and the protective effect of $W$. volubilis root extract against diabetic neuropathy could be due to the presence of these phytoconstituents. However, further 
studies like isolation of the phytoconstituents and their pharmacological evaluation are needed to substantiate the claim.

\section{CONCLUSION}

This study confirms the anti-hyperglycemic activity and neuroprotective effects of $W$. volubilis root in rats in the tested model. Thus the study substantiates traditional claim of Murva vis-a-vis $W$. volubilis as an anti- diabetic drug. However, further studies are needed to elucidate the mechanism(s) of action and to identify the active principle/s responsible for producing these activities.

\section{ACKNOWLEDGEMENTS}

The authors acknowledge the Dean Faculty of Pharmacy and Management of M.S. Ramaiah University of Applied Sciences for supporting this research work.

\section{REFERENCES}

ABELL, L. Standard Methods in Clinical Chemistry. Amsterdam: Science Direct, 1958. p. 26, v.2.

ASSMANN, G. At what levels of total low density lipoprotein cholesterol should diet/drug therapy be initiated European guidelines. Am. J. Cardiol., v.65, n.12, p.11F-15F, 1990.

ASSMANN, G.; SCHRIEWER, H.; SCHMITZ, G. Qualification of high density lipoprotein cholesterol by precipitation with phosphotungstic acid/ $\mathrm{Mg} / \mathrm{Cl}_{2}$. Clin. Chem., v.29, n.12, p. 2026-2030, 1983.

BABLOK, W., et al. A General Regression Procedure for Method Transformation. J. Clin. Chem. Clin. Biochem., v.26, n.11, p.783-790, 1988.

BOLZAIN, A.D.; BIANCHI, M.S. Genotoxicity of streprozocin. Mutat. Res., v.512, n.2-3, p.121-134, 2002.

BOULTON, A.J.; VINIK, A.I.; AREZZO, J.C.; BRIL, V.; FELDMAN, E.L.; FREEMAN, R.; MALIK, R.A.; MASER, R.E.; SOSENKO, J.M.; ZIEGLER, D.; AMERICAN DIABETES ASSOCIATION. Diabetic neuropathies: a statement by the American Diabetes Association. Diabetes Care., v.28, n.4, p.956-962, 2005.
DAVIDSON, M.B. Diabetic ketoacidosis and hyperosmolar nonketotic coma. In: DAVIDSON,M.B. (Ed). Diabetes Mellitus: diagnosis and treatment. New York: Wiley medical, 1981. p.193-241.

DUMAS, B.T.; WATSON, W.A; BIGGS, H.G. Albumin standards and the measurement of serum albumin with bromcresol green. 1971. Clin. Chem. Acta., v. 258, n.1, p. 21-30, 1997.

GAMBLE, J.S. The flora of the presidency of Madras. Dehra Dun: Bishen Singh Mahendra Pal Singh, 2005. v.2, 845p.

GHAHARY, A.; CHAKRABRTI, S.; SIMA, A.A.; MURPHY, L. $\mathrm{J}$. Effect of insulin and statil on aldose reductase expression in the diabetic rats. Diabetes, v.40, n.1, p.1391-1396, 1991.

GOPAL, V.; MANDAL, V.; MANDAL, SC. HPTLC evaluation of oleanolic acid and ursolic acid from the methanol extract of Wattakaka volubilis. J. Acute Dis., v.3, n.1, p.59-61, 2014.

GURUDEVA, M.R. Botanical and vernacular names of south indian plants. Bangalore: Divyachandra Prakashana, 2001. $945 \mathrm{p}$.

GUPTA, R.; GUPTA, H.P.; KUMAR, N.; JOSHI, A.K.; GUPTA, V.P. Lipoprotein lipids and prevalence of hyperlipidemia in rural India. J. Cardiovasc. Risk, v.1, n.2, p.179-184, 1994.

HARBORNE, J.B. Phytochemical methods. 3.ed. London: Chapman and Hall; 1998. p. 4-7.

JAIN, S.P.;VERMA, D.M. Medicinal plant in the folk-lore of north-east Haryana. Nat. Acad. Sci. Let., v.4, p.269-271, 1981.

JAIN, S.K.; RAO, R.R. Field and herbarium methods. New Delhi: Today and Tomorrow Publishers; 1985.

JANG, J.J.; HO, H.V.; KWAN, H.H.; FAJARDO LF.; COOKE, J.P. Angiogenesis is impaired by hypercholesterolemia role of asymmetric dimethylarginine. Circulation, v.102, n.12, p.1414-1419, 2000.

JUNOD, A.; LAMBERT, A.E.; STAUFFACHER, W.; RENOLD, A.E. Diabetogenic action of streptozotocin: relationship of dose to metabolic response. J. Clin. Invest., v.48, n.11, p. 2129-2139, 1969. 
JOSEPH, B.; JINI, D. An insight into hypoglycemic effect of traditional Indian herbs used in the treatment of Diabetes. Res. J. Med. Plant., v.8, p.352-376, 2011.

JOSHI, A,B.; ANVEKAR, P.K.; BHOBE, M.P. Phytochemical investigation of the roots of Wattakaka volubilis. Pharm. Chem., v. 5, n.3, p.112-115, 2013.

KOKATE, C.K. Practical pharmacognosy. 4th ed. New Delhi: Vallabh Prakashan; 1999. p.107-111, 124-125.

KONERI, R.B.; SAMADDAR, S.; SIMI, S.M.; SRINIVAS, T.R. Neuroprotective effect of a triterpenoidsaponin isolated from Momordica cymbalaria Fenzl in diabetic peripheral neuropathy. Indian J. Pharmacol., v.46, n.1, p.76-81, 2014.

LEE, H.; LIN, J.Y. Antimutagenic activity of the extracts from anticancer drugs in Chinese medicine. Mutat Res., v.204, p.229-234, 1998. [PMID:3278214]

LI, M.; QU, W.; WANG, Y.; WAN, H.; TIAN, C. Hypoglycemic effect of saponin from Tribulus terrestris. Zhong Yao Cai., v. 25, n.6, p.420-422, 2002.

LEVEKAR, G.S.; CHANDRAN, K.; DHAN, B.P.; MANGAL, A.K.; RAJESH DABUR; ARUN, M. G. Data base on medicinal plants used in Ayurveda and Siddha. New Delhi: Central Council for Research in Ayurveda and Siddha, 2007. v.8, p.272-282.

MADHAVAN, V.; SHUKLA, A.K.; MURALI, A.; USHA, M.; YOGANARASIMAN, S.N. Antipyretic activity studies of two botanical sources of the drug Murva. Asian J. Trad. Med., v.5, n.5, p. 171-180, 2010.

MADHAVAN, V.; GORAVANKOLLA, A.K.; MURALI, A.; YOGANARASIMAN, S.N. Wound healing activity of the leaves of Wattakaka volubilis (L.f.) Stapf(Asclepiadaceae). Int. J. App. Res. Nat. Prod., v.5, n.3, p.23-29, 2012.

MOHAN, V.R.; MARUTHUPANDIAN, A.; SAMPATHRAJ, R. Antidiabetic, antihyperlipidemic, and antioxidant activity of Wattakaka volubilis (L.F) Stapf leaves in alloxan induced diabetic rats. Int. J. Pharm. Sci. Res., v.1, p. 83-90, 2010.

MUTHU, C.; AYYANAR, M.; RAJA, N.; IGNACIMUTHU, $\mathrm{S}$. Medicinal plants used by traditional healers in Kancheepuram District of Tamil Nadu. J. Ethnobiomed., v.2, p. 43-52, 2006.
MURTHY, K.R.; YOGANARASIMHAN, S.N. Flora of Croog (Karnataka, India). Bangalore: Vismat Publishers; 1990. p. 224.

NAYAK, A. In vitro hypoglycaemic activity evaluation of Marsdenia tenacissima and Sphaeranthus indicus. Inventi Rapid. J. Ethnopharmacol., v.3; 2014.

CARROLL, N.V.; LONGLEY, R.W.; ROE, J.H. The determination of glycogen in the muscle by the use of anthrone reagent. J. Biol. Chem., v.220, n.2, p.583-593, 1955

NIRANJAN, R.V.L.; RAVIKANTH, V.; VIJENDRA, R.A.; PRABHAKAR, R.T.; VENKATESWARLU, Y. An unusual novel triterpenoidether, multiflor-7-en-12,13- ether and a new multiflor 7 -en- $12 \alpha$-ol from Wattakaka volubilis. Tetrahed. Lett.,v.43, p.1307-1311, 2002.

Organization for Economic Co-operation and Development (OECD) Guideline No. 423. Acute oral toxicity in animals. OECD/OCDE No. 423, adopted 17th December, 2001. Availablefrom: http://www.ntp.niehs.nih.gov/iccvam/ suppdocs/feddocs/oecd/oecd_gl423.pdf. [Last cited on 2015 Feb 19].

PANDI, K.P.; AYYANAR, M.; IGNACIMUTHU, S. Medicinal plants used by Malasar tribes of Coimbatore district, Tamil Nadu. Indian J. Trad. Knowl., v.6, p. 579-582, 2007.

PIRART, J. Diabetes Mellitus and its Degenerative Complications: A Prospective Study of 4,400 Patients Observed Between 1947 and 1973. Diab Care., v.1, p.168$188,1978$.

RAJADURAI, M.; VIDHYA, V.G.; RAMYA, M.; BHASKAR, A. Ethno-Medicinal plants used by the Traditional Healers of Pacchamalai Hills, Tamil Nadu. India. J. Ethnobiol. Ethnomed., v.3, p.39-41, 2009.

RAJALINGAM, R.; SRINIVASAN, N.; GOVINDARAJULU, P. Effect of alloxan induced diabetes on lipid profiles in renal cortex and medulla of mature albino rats. Indian $J$. Exp. Biol., v.31, n.6, p.577-579, 1993.

RAKIETEN, N.; RAKIETEN, M.L.; NADKARNI, M.V. Studies on the diabetogenic action of streptozotocin (NSC37917). Cancer Chemother. Rep., v. 29, p.91-102, 1963. 
RASTOGI, R.P.; MEHROTRA, B.N. Compendium of Indian Medicinal plants. Lucknow CDRI; New Delhi: NISC 19801984. v. 3, p.678-9.

RASTOGI, R.P.; MEHROTRA, B.N. Compendium of Indian Medicinal plants. Lucknow CDRI; New Delhi: NISC 1985. v.4, p. 763 .

RAZ, I.; HASDAI, D.; SELTZER, Z.; MELMED, R.N. Effect of hyperglycemia on pain perception and on efficacy of morphine analgesia in rats. Diabetes., v.37, n.9, p.12531259,1988 .

RODRIGUES, B.; CAM, M.C.; KONG, J.; GOYAL, R.K.; MCNEILL, J.H. Strain differences in susceptibility to streptozotocin-induced diabetes Effect on hypertriglyceridemia and cardiomyopathy. Cardiovasc. Res., v.34, n.1, p. 199-205, 1997.

SALDANHA, C.J.; NICOLSON, D.H. Flora of Hassan District, Karnataka v.1, New Delhi: Amerind Publishing Co,1976. $455 \mathrm{p}$.

SANYASI, R.M.L.; VERMA, Y.N.R.; KUMAR, V. Apply leaf juice by adding little lime on affected part to cure sprains once day till cured. Ethno. Bot. Leaflets., v.12, p.217-226, 2008.

SHAU N, P.; PANDA, N.; MANDAL, N.B.; BANERJEE, S.; KOIKE, K.; NIKAIDO, T. Polyoxy-pregnane glycosides from the flowers of Dregea volubilis. Phytochemistry., v.61, p.383-388, 2002.

SHIBU, A.; DHANAM, S. Antibacterial efficacy of leaf, stem and root powders of Gmelinaasiatica (L.) and Wattakaka volubilis (L. f) Stapf. Int. J. Cur. Tr. Res., v.2, n.1, p.100104, 2013.

SILIJA, V.P.; VARMA, S.K.; MOHANAN, K.V. Ethnomedicinal plant knowledge of the Mullukuruma tribe of Wayanand district, Kerala. Ind. J. Trad. Knowl., v.7, p. 604-612, 2008.

SIMON, G.S.; DEWEY, W.L. Effect of streptozotocin-induced diabetes on the anti-nociceptive potency of morphine. $J$ .Pharmacol. Exp. Ther., v.218, p.318-323, 1981.

SINGH, U.K.; GOVIL, J.N.; SINGH, G. Recent progress in Medicinal plants in Ayurveda and Siddha. New Delhi: Central Council for Research in Ayurveda and Siddha, 2007. p. 272-278.
SRIVASTAVA, S.K.; RAMANA, K.V.; BHATNAGAR, A. Role of aldose reductase and oxidative damage in diabetes and the consequent potential for therapeutic options. Endocrine Rev., v.26, p.380-392, 2005.

STAHL, E. Thin layer chromatography: a laboratory handbook. 2.ed. Berlin: Springer, 2005. p. 60-67, 425-69.

SUGIMOTO, K.; YASUJIMA, M.; YAGIHASHI, S. Role of advanced glycation end products in diabetic neuropathy. Curr. Pharm. Design., v.14, n.10, p. 953-961, 2008.

SURESH, B.P.; SRINIVASAN, K. Influence of dietary capsaicin and onion on the metabolic abnormalities associated with streptozotocin induced diabetes mellitus. Mol. Cell. Biochem., v.175, n.1-2, p.49-57, 1997.

TEMME, E.H.; VAN HOYDONCK, P.G.; SCHOUTEN, E.G.; KESTELOOT, H. Effects of a plant sterol-enriched spread on serum lipids and lipoproteins in mildly hypercholesterolemic subjects. Acta Cardiol., v.57, n.2, p.111-115, 2002.

TRINDER, P. Estimation of serum glucose. Ann. Clin. Biol. Chem., p.6-24, 1969.

TULAPORN, W.; SITHIPORN, A. Sex-related differences in cisplatin-induced neuropathy in rats. J. Med. Assoc. Thai., v.92, p.1485-1491, 2009.

VAN DER VIES J. Two methods for the determination of glycogen in liver. Biochem. J., v.57, p. 410-416, 1954.

VOGEL, W.H.; SCHOLKENS, B.A.; SANDOW, J.; MULLER, G.;VOGEL, W.F. Drug discovery and evaluation, pharmacological assays. 2. ed. Berlin Heidelberg: SpringerVerlag, 2002. p.951-952.

WAGNER, H.; BLADT, S. Plant Drug Analysis. 2.ed. Berlin: Springer, 1996. p.54- 254.

YADAV, U.C.; MOORTHY, K.; BAQUER, N.Z. Combined treatment of sodium orthovanadate and Mormodica charantia fruit extract prevents alterations in lipid profile and lipogenic enzymes in alloxan diabetic rats. Mol. Cell. Biochem., v.268, n.1-2, p.111-120, 2005. 
YAMAGISHI, S.I.; OGASAWARA, S.; MIZUKAMI, H.; YAJIMA, N.; WADA, R.; SUGAWARA, A.; YAGIHASHI, $\mathrm{S}$. Correction of protein kinase $\mathrm{C}$ activity and macrophage migration in peripheral nerve by pioglitazone, peroxisome proliferator activated- $\gamma$-ligand, in insulin-deficient diabetic rats. J. Neurochem., v.104, n.2, p.491-499, 2008.

YOGANARASIMHAN, S.N. Medicinal plants of India: Tamil Nadu. Bangalore: Cyber Media, 2000. v.2. 589p.
ZOCHODNE, D.W.; VERGE, V.M.; CHENG, C.; SUN, H.; JOHNSTON, J. Does diabetes target ganglion neurons? Progressive sensory neuron involvement in long-term experimental diabetes. Brain, v.124, pt.11, p.2319-2334, 2001.

Received for publication on $27^{\text {th }}$ July 2015 Accepted for publication on $02^{\text {nd }}$ June 2016 